\title{
WEARING RELIGIOUS SYMBOLS AT WORK IN THE ECTHR'S JUDGMENTS
}

DOI: http://dx.doi.org/10.12775/TSP-W.2020.007

Date of receipt: 25.04 .2020

Date of acceptance: 15.09 .2020

\begin{abstract}
Summary. Freedom of speech and freedom of conscience and religion are essential human rights which are protected, among others, by the ECHR. The number of the European Court of Human Rights' decisions on wearing religious symbols (in a form of a Christian cross, a Muslim veil or a headscarf) at work remains small. Nevertheless, some interpretation guidelines can be identified in particular on how to ensure that an interference with Article 9 of the 1950 Convention has to be proportionate and "necessary in a democratic society". Owing to a lack of European-wide consensus on states' approach to religion, a state exercises a wide margin of appreciation. Nevertheless, a state always has to take into account rights of the others, in particular those who are dependent on (e.g. patience at hospital) employees or are prone to an impact of employees (e.g. pupils and students). Thus, dress codes confirming a secular nature and religious neutrality of a State not always violates Article 9 of the ECHR. Rules apply mainly to public bodies, but a state liability may also be found to private company's cases. Details of each employment contract and of the employee's conduct have to be always analysed. The dress code rules applied to man and women and irrespective to their religion, so the Court has not declared it to be discriminatory because of sex or religion of employees.
\end{abstract}

${ }^{1}$ Dr Piotr Sadowski - Department of Human Rights, Faculty of Law and Administration, Nicolaus Copernicus University in Toruń, ORCID 0000-0002-7013-3410, e-mail: psadowski@ umk.pl. 
Keywords: freedom of religion; religious symbols; clothes and jewellery as religious symbols; employment conditions; Strasbourg case-law.

Noszenie symboli religijnych w pracy w świetle wyroków ETPCz - Wolność słowa oraz wolność sumienia i religii to podstawowe prawa człowieka, które są chronione m.in. przez ETPCz. Liczba orzeczeń Europejskiego Trybunału Praw Człowieka dotyczących noszenia symboli religijnych (w postaci chrześcijańskiego krzyża, muzułmańskiego welonu czy chusty) w miejscu pracy jest w dalszym ciągu niewielka. Niemniej można wskazać pewne wytyczne interpretacyjne, w szczególności dotyczące sposobu zapewnienia, że ingerencja w art. 9 Konwencji z 1950 r. musi być proporcjonalna i ,niezbędna w demokratycznym społeczeństwie”. Ze względu na brak ogólnoeuropejskiego konsensusu w sprawie podejścia państw do religii, państwo korzysta z szerokiego marginesu uznaniowości. Z drugiej strony, państwo zawsze musi brać pod uwagę prawa innych osób, w szczególności zależnych od pracowników (np. pacjentów w szpitalu) lub podatnych na wpływy pracowników (np. uczniów i studentów). Dlatego też zasady ubioru potwierdzające świecki charakter i neutralność religijną państwa nie zawsze naruszają artykuł 9 Europejskiej Konwencji Praw Człowieka. Przepisy dotyczą głównie instytucji publicznych, natomiast odpowiedzialność państwa może być stwierdzona również w przypadku przedsiębiorstw prywatnych. Należy zawsze dokonywać analizy szczegółów każdej umowy o pracę oraz postępowania pracownika. Zasady ubioru obowiązują mężczyzn i kobiety oraz niezależnie od ich wyznania, dlatego Trybunał nie uznał ich za dyskryminujące ze względu na płeć lub religię pracowników.

Słowa kluczowe: orzecznictwo, wolność słowa, godność.

\section{NINTRODUCTION}

Freedom of speech, conscience and religion can be viewed from a number of viewpoints. Hence, these themes can be analysed focusing on, among others, constitutional law, employment law, criminal law, but most of all - international law. However, a cross-cutting perspective which encompasses different aspects of law deserves a presentation in this monograph too. Human rights approach cannot, therefore, be ignored.

This article will focus on religious symbols at work. It will be limited to symbols which are visible to others. I will refer only to "wearing" religious symbols which for the purpose of this text will be understood broadly, because these symbols may take different forms like a small cross, a headscarf or a beard.

From human rights perspective wearing of religious symbols can be perceived as a right to private life, freedom of religion or freedom of expression. All of these aspects are regulated by national laws, including constitutions. Nevertheless, this article would limit divagations to international law, focusing on the 
Council of Europe's ECHR. This is the best well-known and the most efficient instrument of protection of human rights in Europe. It is also the most easily and widely available protection system, because every individual who claims that his/her rights were infringed by a State-Party to the ECHR may bring his/ her case to the European Court of Human Rights (the ECtHR, the Court), if he/ she has meet prerequisites specified in that law. The Convention binds all of the CoE Member States (the CoE MS), but it is also a minimum standard for the European Union (the EU) ${ }^{2}$.

The text will be focused on decisions of the $\mathrm{ECtHR}^{3}$, as they provide real-life examples of the challenges which individuals face in employment and in prolonging their employment contracts. Hence, the article will not address a recruitment. The analysed judgments focus on woman wearing hijabs at a school, at the university and in hospital ${ }^{4}$, as well as small crucifix ${ }^{5}$. In all cases an employment relationship was essential. Hence, wearing of religious symbols at the university by students (cf. Leyla Şahin v. Turkey ${ }^{6}$ ) and in public places (cf. S.A.S. v. France ${ }^{7}$ ) will not be analysed in this text.

Part 1 of this article will focus on a relationship between the universal and regional systems of human rights protection to stress the importance of the ECHR for the CoE and for the EU. Subsequent part will present human rights approach to religious symbols at work. In part 3 the ECHR decisions on wearing religious symbols at work will be briefly discussed. Finally, main interpretation lines from these decisions will be outlined in part 4 . The article ends with concluding remarks.

\section{THE ECHR IN A CONTEXT}

Wearing religious symbols at work have been referred to in a number of international law instruments. Some of them were adopted by the United Na-

${ }^{2}$ See Article 53 of Charter of Fundamental Rights of the European Union, Consolidated text OJ EU C 115. More in P. Sadowski, A Safe Harbour or a Sinking Ship? On the Fundamental Rights in Recent Judgments of the CJEU on Asylum, „European Journal of Legal Studies” 2019, Vol. 11, No. 2.

${ }^{3}$ All decisions of the ECtHR are available at: https://hudoc.echr.coe.int/.

${ }^{4}$ Respectively: ECtHR, Dahlab v. Switzerland, 15 February 2001, App. No. 42393/98; ECtHR, Kurtulmuş v. Turkey, 24 January 2006, App. No. 65500/01.

${ }^{5}$ ECtHR, Eweida and Others v. the United Kingdom, 15 January 2013, App. nos. 48420/10, 59842/10, 51671/10 and 36516/10.

${ }^{6}$ ECtHR, Leyla Şahin v. Turkey, 10 November 2005, App. No. 44774/98.

${ }^{7}$ ECtHR, S.A.S. v. France, 1 July 2014, App. No. 43835/11. 
tions (the UN). Its Universal Declaration of Human Rights ${ }^{8}$ is the most widely recognised document addressing human rights. It has become an uncontested source of inspiration to more detailed binding regulations ${ }^{9}$. However, it is difficult to establish and to raise a common level of human rights protection at the UN level owing to e.g. legislative, cultural and economic differences between the UN states. Regional international organisations help to overcome these obstacles (their laws have to be in-line with the UN ones). In Europe the CoE and the EU are at the forefront of a battle for human rights.

The Council of Europe is the oldest European organisation focusing on human rights. Its landmark European Convention on Human Rights is a general human rights treaty as it is not limited thematically or subjectively. Hence, it addresses all human rights of all individuals. A practical importance of the ECHR has increased significantly when the ECtHR became a permanently sitting tribunal ${ }^{10}$, to which all persons under the jurisdiction of the CoE MS (47 member states, 27 of which are members of the EU) may apply directly, when they meet criteria established by the ECHR. The Court is not, however, another instance in a court procedure, because case can be addressed to the Strasbourg court when the national procedures were exhausted. This ensures that national authorities bear their primary responsibility for efficient respect to human rights what is subject to the control of a state-independent body (the ECtHR).

Decisions of the ECtHR are binding inter partes, so they affect only parties to the judgment. The Court is, however, consistent in its interpretation of the ECHR, although there is no precedent de jure. Thus, decisions made against the above-cited CoE MS may have an indirect impact on other parties. In other words, a precedent de facto is grounded on a view that a State would receive like decision if the case would be like the one which had been decided ${ }^{11}$.

The Convention also has an impact on other legal regimes. The European Union (formerly: the European Communities, the EC), contrary to the CoE, were initially not focused on human rights. Nevertheless, as the EC's/EU's competencies expanded, the Luxembourg judges (the ECJ) and later - the EC/EU trea-

${ }^{8}$ Resolution 217 A (III) of 10 December 1948, Paris.

${ }^{9}$ Including e.g. International Covenant on Civil and Political Rights Adopted and opened for signature, ratification and accession by General Assembly resolution 2200A (XXI) of 16 December 1966.

${ }^{10}$ Protocol No. 11 to the Convention for the Protection of Human Rights and Fundamental Freedoms, Restructuring the Control Machinery Established Thereby of 23 November 1994, ETS No. 155.

${ }^{11}$ More in M. Balcerzak, Zagadnienie precedensu w prawie międzynarodowym praw człowieka, Toruń 2008, pp. 32-40. 
ties - were more and more frequently referring to these rights ${ }^{12}$. In that way the ECHR have an impact on EU law, particularly because the ECJ "was inspired" by the ECtHR's judgments and it referred to its interpretation of rights defined in the Convention ${ }^{13}$. Hence, human rights expanded into policy areas in which they were initially only incidentally regulated by the $\mathrm{EC} / \mathrm{EU}^{14}$.

The situation changed when the Treaty of Lisbon entered into force in 2009. Article 6 of the Treaty on the European Union imposes an obligation on the EU to accede to the ECHR. Additionally, the Charter of Fundamental Rights of the European Union (the Charter) got it legal power equal to the Treaties (before it was proclaimed as a political declaration). Consequently, the EU got its own document setting the EU human rights protection standard. Article 52(3) of the Charter provides that the ECHR sets out the minimum standard for the EU ${ }^{15}$. Hence, the EU may establish a higher (e.g. a more detailed) standard than the CoE. Council Directive 2000/78/EC of 27 November 2000 establishing a general framework for equal treatment in employment and occupation ${ }^{16}$ exemplifies this approach.

The Luxembourg judges have already referred to the discrimination on grounds of religion and belief in the employment context. First judgments on this theme were made in $2017^{17}$ and focused on the Directive 2000/78/EC. Achbita focused on the company's neutrality policy that took a form of "a prohibition on employees from wearing any political, philosophical or religious signs

${ }^{12}$ More in e.g. S. Brittain, The Relationship Between the EU Charter of Fundamental Rights and the European Convention on Human Rights: an Originalist Analysis, „European Constitutional Law Review" 2015, Vol. 11, No. 03; G. de Búrca, After the EU Charter of Fundamental Rights: The Court of Justice as a Human Rights Adjudicator?, „Maastricht Journal of European and Comparative Law" 2013, Vol. 20, No. 2.

13 Cf. CJEU, C-36/02 Omega Spielhallen- und Automatenaufstellungs-GmbH v Oberbürgermeisterin der Bundesstadt Bonn, 14 October 2004, ECLI:EU:C:2004:614, §3. All decisions of this tribunal are available at https://curia.europa.eu

14 E. Muir, The Fundamental Rights Implications of EU Legislation: Some Constitutional Challenges, „Common Market Law Review” 2014, Vol. 51, No. 1, pp. 226-227.

15 More in B. Gronowska, J. Maliszewska-Nienartowicz, The EU Charter on Fundamental Rights - do we really need it? [in:] European Union at the Crossroads: the Need for Constitutional and Economic Changes, Torun 2007; G. de Búrca, The Evolution of EU Human Rights Law [in:] The evolution of EU law, P. P. Craig, G. de Búrca (eds.), Oxford; New York 2011; S. Brittain, The Relationship, op.cit.

16 OJ EC L 303.

17 CJEU, C-157/15 Achbita, Centrum voor Gelijkheid van kansen en voor racismebestrijding v G4S Secure Solutions, 14 March 2017, ECLI:EU:C:2017:203; CJEU, C-188/15 Bougnaoui and Association de défense des droits de l'homme (ADDH) v Micropole Univers, 14 March 2017, ECLI:EU:C:2017:204. 
while on duty". Cases are interesting ${ }^{18}$ also because Advocate Generals made contradictory opinions to answer a question if the employer's religious beliefs may be left behind the employer's door ${ }^{19}$. Scholars claimed that a late appearance of this theme in the ECJ made that court be "expected to position itself by reference to the ECtHR's case law on religious garments and to delineate how the Directive should be interpreted in religious discrimination instances for future references" ${ }^{20}$. Looking at that court practice in other areas of EU law we may, however, say that citations of the ECHR and the ECtHR's decisions will be made when new aspects of EU law will be analysed ${ }^{21}$.

\section{WEARING RELIGIOUS SYMBOLS - FREEDOM OF RELIGION OR RESPECT TO RIGHT TO PRIVATE LIFE?}

Selection and wearing of clothes can be seen from a perspective of a freedom to religion. We should, therefore, recall that during the works on the ECtHR it was subject to disputes how the term "religion" should be defined. Owing to the lack of a consensus between the CoE MS the Authors of that treaty decided to leave this issue to national states. However, the ECtHR made it clear that the "manifestation" of religion or belief within the meaning of Article 9 of the ECHR is not limited to acts of worship or devotion which form part of the practice of a religion or belief "in a generally recognised form" 22 .

The first judgment of the ECtHR regarding freedom of religion was made in $1993^{23}$, and since then the number of cases has been growing ${ }^{24}$. In $\S 31$ of Kokkinakis the Court clearly stated that: "freedom of thought, conscience and religion is one of the foundations of a »democratic society « within the meaning of the Convention. It is, in its religious dimension, one of the most vital elements that

${ }^{18}$ More in E. Howard, Islamic headscarves and the CJEU: Achbita and Bougnaoui, ,Maastricht Journal of European and Comparative Law" 2017, Vol. 24, No. 3.

${ }^{19}$ K. Pavlidou, Religious Expression in the Workplace Before the European Court of Human Rights and the Court of Justice of the European Union: Discriminating Against a Fundamental Right? [in:] Applying Non-Discrimination Law, Goulas, D., Kofinis, St. (eds.), Thessaloniki 2018, s. 150 .

${ }^{20}$ Ibidem., s. 147.

${ }^{21}$ More in P. Sadowski, A Safe Harbour, op.cit.

${ }^{22}$ ECtHR, Decision as to the Admissibility in Shirley Porter v. the United Kingdom, 8 April 2003, App. No. 15814/02, §3.

${ }^{23}$ ECtHR, Kokkinakis v. Greece, 25 May 1993, App. No. 14307/88, §31.

${ }^{24}$ B. Gronowska, Europejski Trybunat Praw Człowieka. W poszukiwaniu efektywnej ochrony praw jednostki, Toruń 2011, p. 173. 
go to make up the identity of believers and their conception of life, but it is also a precious asset for atheists, agnostics, sceptics and the unconcerned. The pluralism indissociable from a democratic society, which has been dearly won over the centuries, depends on it.". This passage has been repeatedly cited by the Court in e.g. Dahlab. The Kokkinakis was made 43 years after negotiations of the ECHR, but the ECtHR still could not find a European-wide consensus on this issue. Because of that, the Strasbourg judges stressed that the CoE MS exercise a wide margin of appreciation in regulating freedom of religion issues ${ }^{25}$.

It is undisputed that wearing of religious symbols is considered as the manifestation of religion. This is the case also e.g. when a person has these symbols at work. These symbols may, certainly, take different forms as they are connected with the religion of the believer. They can be small crucifixes (in a form of a jewellery as in Eweida) or "to face-covering clothing (such as the burqa and niqab)"26, Muslim veils ${ }^{27}$, or Sikh's a bangle or kirpan ${ }^{28}$.

Moreover, the ECtHR recognised in, inter alia, in $\$ 107$ of S.A.S. that "personal choices as to an individual's desired appearance, whether in public or in private places, relate to the expression of his or her personality and thus fall within the notion of private life. It has found to this effect previously as regards a haircut (...). It considers (...) that this is also true for a choice of clothing. A measure emanating from a public authority which restricts a choice of this kind will therefore (...) fall under Article 8 of the Convention.". Thus, the Court stressed that such a limitation "mainly raises an issue with regard to the freedom to manifest one's religion or beliefs (...) [,but it] examine[d] this part of the application under both Article 8 and Article 9, but with emphasis on the second of those provisions.". The same was raised by the applicant in Kurtulmuş but the Court has not elaborated on this in that judgment.

\section{DAHLAB V. SWITZERLAND}

For the first time the ECtHR focused on religious symbols at work in Dahl$a b$. The Court addressed an issue of "wearing an Islamic headscarf [by a primary

${ }^{25}$ More in L. Garlicki, Wartości lokalne a orzecznictwo ponadnarodowe - „kulturowy margines oceny” w orzecznictwie strasburskim?, „Europejski Przegląd Sądowy” 2008, No. 4.

${ }^{26}$ ECtHR, Hamidović v. Bosnia and Herzegovina, 5 December 2017, App. No. 57792/15, §22. For wearing a burqa and a niqab in public places see S.A.S.

${ }^{27}$ Dahlab; Eweida; ECtHR, Ebrahimian v. France, 26 November 2015, App. No. 64846/11.

${ }^{28}$ Cf. ECtHR, Ahmet Arslan and Others v. Turkey, 23 February 2010, App. No. 41135/98. It focused on public places. 
school teacher] in class (...), her intention being to observe a precept laid down in the Koran whereby women were enjoined to draw their veils over themselves in the presence of men and male adolescents". Firstly, when Ms Dahlab started her work as a teacher the law regulated religious neutrality in public schools. Secondly, she started to work at a state school as a Christian and converted after some months of teaching. Thirdly, a quality of her teaching skills was never questioned by her supervisors or by her pupils' parents and "her teaching (...) was secular in nature". Fourthly, the parents did not contest the fact that she was wearing a headscarf at work. Fifthly, after a certain period of time Ms Dahlab was asked by authorities to stop wearing the headscarf while carrying out her professional duties, as such conduct was incompatible with the law, but she refused.

In response to the application, the Government stated that the principle that State schools were non-denominational was introduced before the Applicant took the position at school and at that moment she had compiled with national law. She was a civil servant - a representative of a State, so "her conduct should not suggest that the State identified itself with one religion rather than another. That was especially valid where allegiance to a particular religion was manifested by a powerful religious symbol, such as the wearing of an Islamic headscarf.". As a qualified teacher she could start teaching infant classes at private schools which "were not bound by the requirement of secularism".

Judges decided that she was teaching very young children (4-8 years old) who are naturally curious about many things and are also more easily influenced than older pupils. Hence, the wearing of a headscarf might have some kind of proselytising effect. The Court also stressed that an obligation to wear a hijab stems from Koran, but this is hard to square with the principle of gender equality. Hence, the hijab contradicts a tolerance and religious harmony, which the teacher has to teach. Thus, actions taken by a State were proportionate, respected a margin of appreciation and were "necessary in a democratic society".

This part of the application was manifestly ill-founded within the meaning of Article 35(3) ${ }^{29}$ of the Convention and was rejected in accordance with Article 35(4) of the ECHR. A remark should be made here. It seems that the Court referred to Article 35(3)(b) of the ECHR according to which the application is manifestly ill-founded if "the applicant has not suffered a significant disadvantage, unless respect for human rights as defined in the Convention and the

${ }^{29}$ M.A. Nowicki claims that there were not many decisions based on this legal ground. M.A. Nowicki, Wokót Konwencji Europejskiej. Komentarz do Europejskiej Konwencji Praw Człowieka, Warszawa 2017, p. 101. This seems not to be the case on wearing religious symbols at work. 
Protocols thereto requires an examination of the application on the merits and provided that no case may be rejected on this ground which has not been duly considered by a domestic tribunal". In all cases discussed below the ECtHR found that national courts paid sufficient attention to the applications. Thus, the Court based its decisions on insignificant disadvantage to the Applicants.

Finally, the ECtHR stressed that the limitation on wearing religious symbols at work was imposed because of the state neutrality. It applied to all persons without prejudice to their sex. Hence, the Court decided that Ms Dahlab was not discriminated because of her sex.

\section{KURTULMUŞ V. TURKEY}

Kurtulmuş also focused on a teacher who was wearing headscarf at work, but she was an associate professor at the University of Istanbul, not a teacher in primary school. The applicant was wearing the Islamic headscarf when she obtained her doctorate in 1992, although the law of 1990 imposed disciplinary sanctions for non-compliance with secularism principle. She was suspended from her duties in 1998 and, consequently, she was given a warning and declared ineligible for promotion for two years because of not meeting the abovementioned requirement, and she received a reprimand for continuing to wear the Islamic headscarf while teaching. Finally, she was deemed to have resigned from her post, again on the ground that she had wilfully failed to comply with the rules applicable to Staff in State Institutions.

The Istanbul Administrative Court rejected the Applicant's complain stressing that she had wilfully and persistently refused to comply with the public servants' dress code, despite being sent numerous reminders. Judges stressed that the decision had been taken in accordance with the relevant procedural rules. Ms Kurtulmuş appealed raising that according to the law she could get a warning or a reprimand, but not more restrictive penalties. The Supreme Administrative Court found it unnecessary to examine her application, because new law introduced an amnesty on disciplinary penalties imposed for disciplinary offences.

In her application to the ECtHR Ms Kurtulmuş cited Articles: 7 (a lack of Turkish law prohibiting female teachers to wear Islamic headscarves), 8 (the ECtHR declared that she repeated her views from Article $9^{30}$ ), 9 (the ban on her wearing a headscarf when teaching had violated her right to manifest religion)

\footnotetext{
${ }^{30}$ The Court limited itself to declare that there was no violation of Article 9 of the ECHR in this case.
} 
and 10 of the ECHR, as well as Article 14 of the Convention taken in conjunction with Articles 9 and 10 (discrimination on the ground that the religious precept that required the headscarf to be worn applied only to Muslim women). Nevertheless, she agreed that penalties were envisaged by Turkish law, they pursued legitimate aims, but she contested that these measures were not "necessary in a democratic society". She further raised "that penalties had been imposed only on teachers who wore the headscarf, despite the fact that the Rules on Dress contained a number of restrictions which were not complied with in practice (such as those concerning the length of skirts and the wearing of sandals)(...)[ what] constituted discrimination within the meaning of Article 14 of the Convention taken in conjunction with Articles 9 and 10. She also complained of sexual discrimination on the ground that the religious precept that required the headscarf to be worn applied only to Muslim women(...), whereas Muslim men were free to go about their occupation without constraint." ${ }^{31}$.

The Strasbourg judges reiterated that a democratic State may require public servants to be loyal to the constitutional principles on which the State is found$\mathrm{ed}^{32}$ when they act as representatives of that State. The rules require their appearance to be neutral to preserve the principle of secularism, which in Turkey had been outlined already in $\$ 114$ of the Leyla Şahin ${ }^{33}$. This does not contest the fact that public servants are at the same time individuals who as such qualify for the protection of Article 9 of the ECHR. The Court also cited Dahleb to reiterate that these rules may not exceed the margin of appreciation if they take into account facts of every case and the need to respect the principle of neutrality. In Kurtulmuş this guarantees were secured because the dress code applied to all public servants, irrespective to their functions or religion.

The Court underlined that the Applicant voluntarily accepted the status of a public servant. She was not immediately asked to remove a headscarf (hence, the law was not rigorously applied), but this does not mean that the law was not in force at that moment (the ECtHR cited Leyla Şahin and Dahlab). The Court declared that Turkey exercised its margin of appreciation on regulating wearing religious symbols, but this interference was justified in principle and proportion-

${ }^{31}$ Kurtulmuş, $\S 2$ of the complaint.

${ }^{32}$ See ECtHR, Vogt v. Germany, 26 September 1995, App. No. 17851/91, Series A No. 323, $\S 53$.

${ }^{33}$ The Court, however, expanded this interpretation to academic teachers in this judgment. The European Court of Human Rights and the freedom of religion or belief: the 25 years since Kokkinakis, J. Temperman, T.J. Gunn, M.D. Evans (esd.), Series „Studies in religion, secular beliefs and human rights", volume 13, Leiden; Boston 2019, p. 340. 
ate to the intended aim to be achieved. The application was, consequently, unanimously rejected as manifestly ill-founded.

Finally, the Court decided that the limitation on wearing religious symbols at work was imposed on all persons irrespective to their sex. Hence, as the manifest purpose of the rules is to preserve both secularism within education institutions and the principle of neutrality of the public service, no violation can be found of Article 9 of the ECHR (read alone or with Article 14 of the Convention).

\section{EWEIDA AND OTHERS V. THE UNITED KINGDOM}

Dahlab concerned a woman who was aware of religious neutrality of her employer when she started to work, but she started to wear an Islamic headscarf after she converted to Islam. This can be contrasted with Eweida, which considered, among others, Christians who visibly wore crosses. There were four Applicants in that case, but I will limit my divagations to the first two of them, because the others did not address wearing religious symbols at work ${ }^{34}$.

Ms Eweida was a practising Coptic Christian who worked as a member of the check-in staff for British Airways Plc (hereinafter: BA), a private company. The second applicant, Ms Chaplin, was also a practising Christian who wore a cross visibly on a chain around her neck since 1971. She started working as a qualified as a nurse in public hospital in 1981, although it was only in 2007 when new tunics were introduced, which made the applicant's cross more visible and accessible, both at the back of her neck and in front.

Both BA and the hospital had unified their uniform policies and precluded wearing religious symbols visibly. Both companies had, however, a procedure of asking managers for refraining from these policies. In practice some "clothing [was] considered by British Airways to be mandatory in certain religions and which could not be concealed under the uniform, (...) [, so]male Sikh employees (...) [could] wear a dark blue or white turban and to display the Sikh bracelet in summer if they obtained authorisation to wear a short-sleeved shirt. Female Muslim ground staff members were authorised to wear hijab (headscarves) in British Airways approved colours." ${ }^{35}$. This can be contrasted with Ms Chaplin case as an introduction of a dress code was justified by an intention to minimise

${ }^{34}$ For other aspects of the judgement cf. M. Skwarzyński, Protecting conscientious objection as the "hard core” of human dignity, „Ius Novum” 2019, Vol. 13, No. 2, pp. 284-285; T. Jasudowicz, Między sumieniem a orzecznictwem Europejskiego Trybunału Praw Człowieka, „Polski Rocznik Praw Człowieka i Prawa Humanitarnego” 2018, Vol. 8, p. 52.

35 Eweida, 11 . 
the risk of cross infection. The Employment Tribunal noted that, on health and safety grounds, another Christian nurse had been requested to remove a cross and chain and two Sikh nurses had been informed that they could not wear a bangle or kirpan and that they complied with these instructions. Two female Muslim doctors were permitted to wear close-fitting "sports" hijab, resembling a balaclava helmet.

Ms Eweida concealed a cross at work at first under her clothing, but in 2006 she started wearing it openly, as a sign of her commitment to her faith. She was asked to remove it or conceal it under the cravat. Two times she reluctantly agreed but she refused to do so at the third time, so she was send home unpaid. BA offered her administrative work without customer contact, which would not have required her to wear a uniform, but she rejected and remained at home until BA amended its rules on uniform and allowed her to display the cross. Ms Eweida addressed the Employment Tribunal claiming discrimination contrary to Article 9 of the Convention. The Tribunal rejected her claim and "found that the visible wearing of a cross was not a mandatory requirement of the Christian faith but Ms Eweida's personal choice. There was no evidence that any other employee (...) had ever made such a request or demand, much less refused to work if it was not met. It followed that (...) [she] had failed to establish that the uniform policy had put Christians generally at a disadvantage, as was necessary in order to establish a claim of indirect discrimination." ${ }^{36}$.

In 2009 (two years after introducing new uniforms policy) Ms Chaplin was asked to remove her necklace. She insisted that the cross was a religious symbol and sought approval to wear it and she presented a couple of alternative solutions, all of which were rejected because of the risk that the cross may cause an injury if an elderly patient pulled on it. Consequently, Ms Chaplin was moved to a non-nursing temporary position which ceased to exist in July 2010. When her responsibilities were changed, "she applied to the Employment Tribunal (...), complaining of both direct and indirect discrimination on religious grounds (...) [, but] the Tribunal held that there was no direct discrimination since the hospital's stance was based on health and safety rather than religious grounds. As regards the complaint of indirect discrimination, it held that there was no evidence that »persons «, other than the applicant, had been put at particular disadvantage. Moreover, the hospital's response to Ms Chaplin's request to wear the crucifix visibly had been proportionate" ${ }^{37}$.

\footnotetext{
36 Ibidem., $\$ 14$.

37 Ibidem., 21 .
} 
Both Applicants were also offered other jobs by their employers and their salaries was unchanged. In both cases the ECtHR agreed with the Applicants that by wearing Catholic religious symbols the applicants wanted to manifest their religious belief and that the refusal by the employers was an interference with their freedom to manifest her religion ${ }^{38}$. However, conclusions if there was a violation of Article 9 of the ECHR in these cases differ.

BA is a private company, so it has to be established whether the state can be attributed an interference of Ms Eweida's freedom. The Court declared that the applicant's case was properly verified by national tribunals (which analyzed the legitimacy of the uniform code and the proportionality of the measures taken by BA), although the United Kingdom did not have legal provisions specifically regulating the wearing of religious clothing and symbols in the workplace ${ }^{39}$. The Court stressed that "the dress code had been in force for some years and had caused no known problem to the applicant or any other member of staff; that Ms Eweida lodged a formal grievance complaint but then decided to arrive at work displaying her cross, without waiting for the results of the grievance procedure; that the issue was conscientiously addressed by British Airways once the complaint had been lodged, involving a consultation process and resulting in a relaxation of the dress code to permit the wearing of visible religious symbols; and that Ms Eweida was offered an administrative post on identical pay" ${ }^{40}$.

However, according to the majority of the Strasbourg judges a fair balance was not struck, because national courts paid too much attention to BA's image and "accorded it too much weight. Ms Eweida's cross was discreet and cannot have detracted from her professional appearance. There was no evidence that the wearing of other, previously authorised, items of religious clothing, such as turbans and hijabs, by other employees, had any negative impact on British Airways' brand or image. Moreover, the fact that the company was able to amend the uniform code to allow for the visible wearing of religious symbolic jewellery demonstrates that the earlier prohibition was not of crucial importance." ${ }^{41}$. The Court, therefore, concluded by five votes to two that there was a violation of Article 9 of the ECHR, but it did not examined separately the applicant's complaint under Article 14 taken in conjunction with Article 9.

Judges Bratza and Björgvinsson delivered their joint partially dissenting opinion to this judgment. They found no violation of Article 9 of the Convention

\footnotetext{
38 Ibidem., $\$ 89$ and 97 read with 64 and 67.

${ }^{39}$ Ibidem., $\$ 92$.

${ }^{40}$ Ibidem., $\$ 93$.

${ }^{41}$ Ibidem., $\$ 94$.
} 
because according to them BA paid attention to Ms Eweida's concerns, introduced changes to its dress code policy, and that Ms Eweida was not dismissed but offered other duties without changing her salary ${ }^{42}$. In judges' opinion a proper balance of interests was ensured by the Employment Tribunal itself, but not by the Court of Appeal and the ECtHR.

Ms Chaplin was employed at public hospitals. The Court declared it undisputed that "the reason for the restriction on jewellery, including religious symbols, was to protect the health and safety of nurses and patients" ${ }^{43}$. The grounds to introduce the limitation were of a great magnitude and they served a legitimate aim, so a wide margin of appreciation was given to the national authorities. Moreover, the Government declared that "Restrictions were also placed on the wearing of religious items by non-Christians on health and safety grounds: for example, Sikh nurses were not allowed to wear the kara bracelet or the kirpan sword, and Muslim nurses had to wear closely fitted, rather than flowing, hijab" ${ }^{44}$. There was an interference in Ms Chaplin freedom to manifest religion, but the Strasbourg judges unanimously declared that was necessary in a democratic society and that there was no violation of Article 9 of the ECHR in her case. Nevertheless, the Court has not referred to the argumentation of Ms Chaplin that no evidence was adduced before the Employment Tribunal to demonstrate that wearing the cross caused health and safety problems. This approach stays in line with other ECtHR's judgments. Because of the proportionality of measures taken by the hospital to protect legitimate aims the ECtHR found no basis on which it can find a violation of Article 14 of the ECHR in this case.

\section{EBRAHIMIAN V. FRANCE}

Ms Ebrahimian signed a fixed term contract as a social worker in the psychiatric unit at the Nanterre Hospital and Social Care Centre ("the CASH") - a public health establishment. Paris Administrative Court declared that the decision not to renew her contract after certain patients complained in her refusal to stop wearing a head covering was compatible with the principles of secularism and the neutrality of public services. The Court stressed that the CASH adequately assessed her conduct after it "tolerated the wearing of this veil for several months and [even though her] conduct cannot be considered as deliberately provoca-

\footnotetext{
${ }^{42}$ Last of the above-mentioned issues was also raised by the Government. See Ibidem., §59.

${ }^{43}$ Ibidem., $\$ 98$.

${ }^{44}$ Ibidem., $\$ 62$.
} 
tive or proselytising" ${ }^{45}$. Meanwhile, the CASH included her name on the list of candidates for recruitment test, but she did not take part in it. She applied to the Versailles Administrative Court, but it dismissed her request by relying on the principles of a State secularism and the neutrality of public services. That judgment was subsequently uphold. Ms Ebrahimian appealed on points of law to the Conseil d'État and referred to the disproportionate nature of that sanction, and alleged that it had been incompatible with Article 9 of the ECHR, but the court declared this application inadmissible.

The Strasbourg judges indicated that the Applicant was a Muslim, so limitations on wearing a veil resulted in not renewing her employment contract infringed Article 9 of the ECHR. The Court, however, referred the Constitution of France and to the decisions of the Constitutional Council that proved that France is a country of a religious neutrality which is "fundamental principle of public service" ${ }^{" 46}$. The neutrality and impartiality with regard to religious beliefs is also well-settled in French legislation and in decisions of Conseil d'État and the Constitutional Council. These regulations had not explicitly addressed the situation of hospital workers. However, the new Conseil d'État decision (which focused on situation of teachers, but referred to all civil servants) was issued more than six months before a decision on renewal of Ebrahimian's contract was made, so she could start to comply with that decision by non-wearing religious symbols at work.

According to the ECtHR a State must ensure that all persons enjoy equal treatment, without a discrimination based on religion. Hence, limitations on wearing religious symbols pursues a legitimate aim by ensuring secularism and by protecting rights and freedoms of others. This protection does not, however, need to be justified by "public safety" or "protection of public order", but the Court did not referred to "public morality". Limitations may be needed in a democratic society, in which several religions coexist to ensure mutual tolerance between different religious groups, but not to eliminate pluralism. A State must take into account the rights of public servants acting as a representatives of a state, who are at the same time representatives of a state and individuals (the Court cited Kurtulmuş). However, states exercise a wide margin of appreciation (the Court cited Eweida) in that regard. Neutrality, needed to guarantee secular nature of a State, covers not only education, but it is also important to "to the fragility of these users, and (...) [in case of] the applicant [it] was all the more press-

\footnotetext{
45 Ebrahimian, $\$ 11$.

46 Ibidem., \$24-25.
} 
ing in that she was in contact with patients who were fragile or dependent" ${ }^{47}$. Thus, it is important to protect the rights of the others, so "the neutrality of the public hospital service may be regarded as linked to the attitude of its staff, and requires that patients cannot harbour any doubts as to the impartiality of those treating them" $"$.

The Court agreed that domestic courts accurately investigated and weighted the interests of Ms Ebrahimian and a State. The Applicant had time to comply with the Conseil d'État's Opinion on state neutrality, her employer asked her to remove her veil and she was informed why her disciplinary procedure was initiated in her case. Thus, "the Court considers that the domestic authorities did not exceed their margin of appreciation (...) and subsequently in deciding to give priority to the requirement of State neutrality and impartiality"49. The ECtHR also noted a preference to religious neutrality of a state and to emphasis on rights of others over manifestation of religious believes. Consequently, the Strasbourg judges declared by six votes to one that there was an interference with the Applicant's right covered by Article 9 of the ECHR, but it was proportionate to the aims pursued and it was "necessary in a democratic society", so there was no violation of the above-cited law.

Judge O'Leary supported the majority decision, but in her concurring and partly dissenting opinion she stressed an insufficient justification to the case following from an unclear link with the facts of the case on:

1) pursuing legitimate aim by a dress code;

2) the Applicants knowledge at the time of employment about a dress code - the judge stressed that "the wider the margin of appreciation left to States, the more accessible and foreseeable the legal framework on which they rely should be (...) and the majority judgment could be read as assessing the requirement of lawfulness not with reference to the law as it stood then[in 1999-2000] but with reference to the law as it stands now";

3) in Dahlab dress code was analysed by an intimate link to the values which educational establishments are intended to teach and to a state neutrality and secularism, but an expansion of like limitation to hospitals was not analysed in-depth in Ebrahimian.

A dissenting opinion was also given by judge de Gaetano who shared judge O'Leary concerns but he found a violation of Article 9 of the ECHR. He contested:

\footnotetext{
${ }^{47}$ Ibidem., $\$ 61$.

${ }^{48}$ Ibidem., $\$ 64$.

49 Ibidem., \$70.
} 
1) that "the State requires a blanket prohibition on the wearing by a public official at work of any symbol denoting his or her religious belief [, but the ECtHR] (...) proceeds from and rests on the false (and (...) very dangerous) premise (...) that the users of public services cannot be guaranteed an impartial service if the public official serving them manifests in the slightest way his or her religious affiliation - even though quite often, from the very name of the official displayed on the desk or elsewhere, one can be reasonably certain of the religious affiliation of that official" 50 ;

2) a subjective approach to clothes - the judge asked, what is a difference between wearing a headscarf, a necklace or a bear because of religious reasons and because of other reasons and should anybody be obliged to "disclose" these reasons to others;

3) a margin of appreciation on dress code of public service is wide, but limited and exceeding it may contradict the rights and freedoms protected by the ECHR.

\section{HAMIDOVIC V. BOSNIA AND HERZEGOVINA}

A division between wearing religious symbols at work and in public places is not always clear in practice of applying national law, which may broadly define restrictions imposed on individuals. This constrains were exemplified in Hamidović. The Applicant was fined for not agreeing to remove his skullcaps, which the Court could correlate with clothing indicating religious affiliation. National law precluded judges, prosecutors or court officers to wear religious symbols in the course of their duties, but "one judge and approximately ten court officers wore headscarves" ${ }^{51}$. However, the Applicant raised that he was not a public official, so as a private citizen he did not owe a duty of neutrality.

The Strasbourg judges agreed with the Applicant and by six votes to one declared a violation of Article 9 of the ECHR in the present case. Nevertheless, the ECtHR clearly indicated that the "case is not about the wearing of religious symbols and clothing at the workplace (...). Indeed, it concerns a witness in a criminal trial, which is a completely different issue." ${ }^{52}$. The Court added that in Bosnia and Herzegovina this theme is subject to public debate and this issue was

${ }^{50}$ I cannot support the second part of that view, as the name is not a manifestation of a religion and it is something given to a person (not selected by that person), so it is something on what a person has a limited impact.

${ }^{51}$ ECtHR, Hamidović, §14.

${ }^{52}$ Ibidem., $\$ 26$. 
raised in the application, but the ECtHR did not voice its views on wearing religious symbols by judicial officials. This approach court has not provided us with an answer to the question if restrictions imposed on wearing religious symbols by judicial officials is in-line with Article 9 of the ECHR.

The Court's view can be justified on legal grounds. The Strasbourg system of protection of human rights is subsidiary to national one. Moreover, the Applicant referred to the national law which regulated clothing of judges and court officials, although he was a witness in criminal case. Taking this subjective aspect of law into account the ECtHR refrained from applying that law into the current case. Hence, an interpretation of a dress code of court officials was not investigated by the Court.

\section{THE EMPLOYMENT CONTRACT}

The right to choose freely the type of a performed work is secured, among others, in the Universal Declaration of Human Rights, in Article 6 of the International Covenant on Economic, Social and Cultural Rights, Article 1 of the European Social Charter of October 18, 1961, as well as Article 15(1) of the Charter. This right applies to all persons, irrespective to their citizenship, although some professions may not be available to foreigners. It is also uncontested that the establishment of an employment relationship and the determination of essential elements of the contract (e.g. a pay) requires a joint declaration of intent by an employer and an employee. More detailed analysis of the obligatory elements of the contract go beyond the scope of this article. Nevertheless, we should stress that "Protection of freedom of work cannot be understood in terms of exclusively negative freedom (no forced labor). It should be seen as a positive feature - the possibility of exercising the right to work freely chosen thanks to state guarantees." ${ }^{53}$. A question can, however, be asked if the employer buys employees time and readiness to perform an agreed work for an agreed remuneration, or whether the employer buys also employees souls?

We cannot but to stress the fundamental importance of human dignity, which is the source of human rights. This was underlined in many international ${ }^{54}$ and

${ }^{53}$ Cf. T. Zieliński, Rozdział I. Problemy części ogólnej prawa pracy [in:] Prawo pracy RP w obliczu przemian, M. Matey-Tyrowicz, T. Zielinski (eds.), Warszawa 2006, pp. 45-46. Like views [in:] J. Żołyński, Prawo pracy - prawo prywatne czy prawo publiczne. Rozważania na tle charakteru umowy o prace, „Studia z zakresu prawa pracy i polityki społecznej” 2016, No. 23, p. 411.

${ }^{54}$ Cf. the Universal Declaration of Human Rights; International Covenant on Civil and Political Rights; the ECHR; Charter of Fundamental Rights of the European Union. 
national laws. Nobody can be placed in a situation of humiliation, even if this humiliation will appear "only" in his/her own eyes. This rule has been stressed by the ECtHR particularly strongly in a context of Articles 2 and 3 of the ECHR ${ }^{55}$. However, dignity must be respected also at the workplace ${ }^{56}$. Therefore, it should be underlined that by referring to Article 9 of the ECHR in cases focused on wearing a cross visibly the Court explicitly stated in $\$ 65$ of Eweida that this symbol may "be the central image of (...) [the Applicant's] faith; she found the enforcement of the uniform code deeply humiliating and offensive".

There will be no philosophical and ethical divagations in this article. However, we should cite that "a number of other interveners made clear their view that it was quite wrong for an employee to be forced to make the invidious choice between his or her job and faith. The National Secular Society took a different approach, emphasising that the »freedom to resign is the ultimate guarantee of freedom of conscience«. Building on this, they suggested that there existed no positive obligation on a State to protect employees against uniform or other requirements." ${ }^{57}$. The Court, nevertheless, took the opposite view. It contested the European Commission of Human Rights' approach (which declared that an employee's religious freedom is secured in case of a possibility to change employer) and correctly claimed that "No other fundamental right [e.g. Articles 8, 10, 11 of the ECHR ] was subjected to the doctrine that there would be no interference where it was possible for the individual to avoid the restriction, for example by resigning and finding another job" ${ }^{58}$. Consequently the Strasbourg judges ruled that "Given the importance in a democratic society of freedom of religion, the Court considers that, where an individual complains of a restriction on freedom of religion in the workplace, (...) the better approach would be to weigh that possibility in the overall balance when considering whether or not the restriction was proportionate" 59 .

In the analysed cases the quality of the employers' performance was not questioned by the employees. It was only in Ebrahimian in which the recipients of her work had concerns about her wearing religious symbols. Nevertheless, it is unclear to me if they complained on the content of the service which she delivered, or if they considered her image to infringe a dress code. However,

${ }_{55}$ More in B. Gronowska, P. Sadowski, Treatment of Prisoners - International and Polish Perspective, Toruń 2019.

${ }_{56}$ More in D. Dörre-Nowak, Ochrona godności i innych dóbr osobistych pracownika, Warszawa 2005, pp. 1-27.

${ }^{57}$ Eweida, §77.

${ }^{58}$ Ibidem., $\$ 65$.

59 Ibidem., §83; This was also cited in Ebrahimian, $\$ 79$. 
I claim that all disciplinary procedures were initiated because of wearing religious symbols at work, but not on the basis of an ill-performance of an employment contract. A question can, therefore, be asked if in like cases we should seek "some compromise between competing rights was necessary in a democratic and pluralistic society" as it was requested in some third-party interventions in Eweida? In other words, should the Strasbourg judges support:

1) a broad interpretation of a possibility of a "conscientious objection" exception or

2) "[the Alliance Defence Fund which referred] to case-law from the United States of America, which required reasonable accommodation of religious beliefs and practices, insofar as that accommodation did not cause »undue hardship « to the employer" 60 ?

I think that the Court has not given any explicit answer to these questions. However, it noted that Ms Eweida was not disturbed when she was wearing a cross in an invisible to others way and that Ms Kurtulmuş agreed to be punished for wearing a headscarfm but complained on the extend of sanctions which she had to face.

The employers were aware of the sensitive nature of the theme of our interest. I have already discussed how disciplinary proceedings were initiated. However, in all the analysed cases religious symbols were worn visibly for a longer period of time. This explains why Ms Dahlab and Ms Kurtulmuş claimed that their not immediate penalisation for disobeying the law could mean that the law was not in force. The Court, however, correctly rejected that view.

Finally, the employers discussed dress codes rules with the Applicants. Negative consequences were imposed on all Applicants later when they repeatedly refused to change their conducts. Hence, the employers tried to apply less coercive disciplinary sanctions at first. Moreover, Ms Eweida and Ms Chaplin were offered other duties with the same remuneration, which they could perform wearing religious symbols. Ms Ebrahimian did not received such a proposal, but the employer offered her a possibility to participate in a recruitment test. It was only in Ms Dahlan case (the oldest of the analysed judgments) when the government stated that she could take a job in a private school which is not binding with the neutrality principle.

\footnotetext{
${ }^{60}$ Eweida, $\$ 77$.
} 


\section{IS THE ECTHR IMPOSING "FOREIGN" MORALITY?}

It is important to stress that the Court considered situation of Christians (Eweida) and Muslims (other analysed decisions). Interpretations in these cases were like each other. This differs from the ECtHR's decisions on freedom of expression in which the rulings on Christian and Muslim symbols and values vary ${ }^{61}$. All of the analysed judgments focused on citizens of the responded states, so on the members of the "privileged" group ${ }^{62}$, not on immigrants (persons in a vulnerable position resulting from a lack of that citizenship ${ }^{63}$ ). Hence, the Court's approach to wearing religious symbols at work cannot be travestied by a simple question: "is the ECtHR protecting only some religions"?

The Court is accused of imposing foreign morality on the CoE MS ${ }^{64}$. However, in $\S 68$ of Ebrahimian the ECtHR stressed that "the French model [of secularism and state religious neutrality], which it is not the Court's role to assess as such" the above-mentioned principles and the Strasbourg judges only noted that "the regulations of the respondent State place greater emphasis on the rights of others, equal treatment for patients and the proper functioning of the service than on the manifestation of religious beliefs". Consequently, in Ebrahimian the Court widely relied on a margin of appreciation and left more discretion in regulating religious issues to a State.

Nevertheless, the Strasbourg judges partially evaluated the Muslims' approach to gender equality in Dahlab. The ECtHR stressed that the obligation to wear a hijab stems from Koran, but it contradicts with the principle of gender equality, so it disputes a tolerance and a state neutrality. These principles were

61 B. Gronowska, Gloss on the judgment of the European Court of Human Rights of 25 October 2018 in case E.S. v. Austria, appl. No. 38450/12, „Ius Novum” 2019, Vol. 13, No. 2.

${ }^{62}$ Cf. P. Sadowski, Wspólny Europejski System Azylowy - historia, stan obecny i perspektywy rozwoju, Toruń 2019.

${ }^{63}$ Cf. Inter-American Court of Human Rights Advisory Opinion OC-18/03 of September 17, 2003, Requested by the United Mexican States, Juridical Condition and Rights of Undocumented Migrants.

64 This theme is usually invoked in a context of a dynamic interpretation of the ECHR by the ECtHR which is needed to ensure that the interpretation of the Convention reflects current state of e.g. society, technology, morality. That approach of the Strasbourg judges extends the scope of application of the Convention to "an ever-widening range of contexts". More in A. Mowbray, The Creativity of the European Court of Human Rights, „Human Rights Law Review” 2005, Vol. 5, No. 1, p. 58; Evolutive interpretation has been questioned by some States Parties to the ECHR. More in F. de Londras, K. Dzehtsiarou, Managing Judicial Innovation in the European Court of Human Rights, „Human Rights Law Review” 2015, Vol. 15, No. 3, p. 523. 
expressly outlined in law, so the Court could refer to them ${ }^{65}$. Nevertheless, in Eweida the ECtHR indicated that a Christian cross is not a jewellery but it is an expression of a religious symbol which is tightly connected with the Applicant's perception of her dignity.

Can we complain on the Court's reference to a cross as "a powerful religious symbol"? I do not think so, because in Dahlab a Muslim headscarf was called the same. I, therefore, think that it was the message which was associated with the symbol which was "powerful", not the physical symbol itself ${ }^{66} . \S 46$ of Ebrahimian in which the Court declared that the name of the religious symbol is unimportant to decide whether wearing this symbol infringes the law if the law prescribes common features of the forbidden clothing (the applicant raised that she was wearing a scarf similar to Islamic veil but not a veil which was forbidden) confirms my view.

\section{THE SECULAR NATURE OF A STATE AND RELIGIOUS NEUTRALITY OF A STATE}

The secular nature of a state was raised in all of the commented judgments. Base on it the Court declared that a State may impose restrictions on wearing religious symbols by public officials when they are representing that State. This reasoning stems from Article 9 of the ECHR which "recognises that in democratic societies, in which several religions coexist within one and the same population, it may be necessary to place restrictions on this freedom in order to reconcile the interests of the various groups and ensure that everyone's beliefs are respected" ${ }^{67}$. Therefore, "the role of the authorities in such circumstances is not to remove the cause of tension by eliminating pluralism, but to ensure that the competing groups tolerate each other" ${ }^{\prime \prime}$.

Limitations would, certainly, affect civil servants' individualized right guaranteed by Article 9 of the ECHR. This is because according to it "freedom to

${ }^{65}$ This can be contrasted with German Constitutional Tribunal judgment of 24 September 2003, 2BvR 1436/02, in which limitations had no legal ground, so the Tribunal could not express its concerns on an impact of Muslims' headscarves. Contradictory view in D. Janicka, Jurysdykcja państwa niemieckiego $w$ warunkach wielokulturowego społeczeństwa - kilka wybranych przyktadów ze szczególnym uwzględnieniem orzecznictwa administracyjnego i konstytucyjnego, ,Studia Iuridica Toruniensia" 2015, Vol. 15, pp. 65-66.

${ }^{66}$ Hence, I agree with J. Temperman, T.J. Gunn, M.D. Evans (eds.), The European Court, op.cit., p. 342.

${ }^{67}$ Kokkinakis, $\$ 33$.

${ }^{68}$ Ebrahimian, §55 The Court referred to Leyla Şahin. 
manifest one's religion is not only exercisable in community with others, »in public « and within the circle of those whose faith one shares, but can also be asserted $»$ alone $«$ and $»$ in private $" ~ " 69$. However, the above-described interference will not be contested by the ECtHR if a fair balance will be struck between the fundamental right of the individual to freedom of religion and the legitimate interest of a democratic State in ensuring that its public service properly furthers the purposes enumerated in Article 9(2) of the $\mathrm{ECHR}^{70}$. The Court would also leave more margin of appreciation in that regard to the State, because national lawmakers and implementation organs "are better placed to take decisions in their establishments than a court, particularly an international court" ${ }^{\prime 1}$.

It is uncontested that national law may promote secularism and stipulate that it must be obeyed (also in a form of a dress code) by public servants. Nevertheless, there is no European-wide consensus as regards a prohibition imposed on civil servants to wear religious symbols at work. In addition, not all of the $\mathrm{CoE}$ countries established dedicated rules in their national legislation ${ }^{72}$. However, secularism was expressed e.g. in French Constitution (Eweida, §63) and partially in the Swiss Constitution (Dahlab). It was also accepted by constitutional tribunals in France and in Turkey. Contrary to this e.g. in Germany the Constitutional Tribunal ruled that a general prohibition on the wearing of the veil by female teachers in State schools was incompatible with the Constitution, unless it constitutes a sufficiently tangible risk to the State's neutrality or a peaceful environment in schools $^{73}$.

The Strasbourg judges declared that rules on religious neutrality and secularism apply in particular to teachers and representatives of academia, as well as to medical personnel. Thus, we should stress that the public sectors employs ap-

${ }^{69}$ Kokkinakis, $\S 31$.

${ }^{70}$ See Kurtulmuş; Ebrahimian.

71 Ebrahimian, §64; the Court referred to the rule established in Eweida, §99. This approach was also expressed in Ebrahimian, \$69.

72 Eweida, §47; Ebrahimian, §24. In the later judgment this theme was repeated several times and a reference to French Constitutional Council, Decision No. 2012-297 QPC, Association for the Promotion and Expansion of Secular Thought [remuneration of pastors in the consistorial churches in the départements of Bas-Rhin, Haut-Rhin and Moselle] of 21 February 2013 and to French Constitutional Court, Constitutional Court decisions nos. 86-217 DC of 18 September 1986, and 96-380 DC of 23 July 1996 was made.

${ }^{73}$ German Constitutional Tribunal judgment of 24 September 2003, 1 BvR 471/10. More on restrictions imposed on public servants in D. Janicka, Jurysdykcja państwa niemieckiego, op.cit., p. 64 and subsequent. In judgment of 24 September 2003 the Tribunal declared that imposition of that limitation has to be provided for in law. 
proximately 21 percent of all employees ${ }^{74}$. Nevertheless, an application of these rules may not be limited only to persons who perform the above-mentioned duties, but it may expand even to the greater extend. Special dress code may be applied e.g. to witnesses in a criminal procedure (Hamidovic), but these rules have to clearly refer to their situation and rules on wearing religious symbols at work by prosecutors and courts' representatives cannot be applied in extenso to witnesses.

\section{A DRESS CODE - A DISCRIMINATION ON THE GROUNDS OF SEX AND/OR RELIGION?}

A differentiated treatment of persons in like situation which can be objectively justified will not contradict human rights. However, in all cases it has to be verified if this differentiation can be truly justified, and if interference was proportionate to achieve the intended result ${ }^{75}$. Discrimination may take different forms: it can be of a direct or indirect character. Hence, the law which is not discriminatory per se may have an indirect discriminatory effect.

This particular aspect of discrimination was, in my opinion, an important part in the Court's answer to the question if the applicants were discriminated because of their religion and sex (Article 14 of the ECHR read alone or with Article 9 of the ECHR). In Dahlab the Strasbourg judges "reiterates that the advancement of the equality of the sexes is today a major goal in the member States of the Council of Europe. This means that very weighty reasons would have to be advanced before a difference in treatment on the ground of sex could be regarded as compatible with the Convention".

In Dahlab, in Kurtulmuş and in Eweida (in Ms Chaplin context) the Court also stressed that limitations on wearing an Islamic headscarf were imposed purely in the context of the Applicants professional duties. Thus, they were not directed at them as members of the female sex, but pursued the legitimate aim of ensuring the neutrality of all (men and women, irrespective to their faith) public servants.

${ }^{74}$ J. Temperman, T.J. Gunn, M.D. Evans (eds.), The European Court, op.cit., p. 340.

${ }^{75}$ Starting from the ECtHR, Observer and Guardian v. the United Kingdom, 26 November 1991, App. No. 13585/88, Series A No. 216. 


\section{CONCLUDING REMARKS}

There is still no European-wide consensus on religious issues. Therefore, the CoE MS exercise a wide margin of appreciation in that regard. The Commission presented the view that if an individual may change an employer, then no infringement of Article 9 of the ECHR takes place. However, the ECtHR correctly reverted from that interpretation.

Nevertheless, it is clear from the ECtHR's case-law that Article 9 of the ECHR does not protect every act motivated or inspired by a religion or belief, but only if this would contradict the law, which would impose proportionate limitations, which are "necessary in a democratic society". However, there is no requirement on the applicant to establish that he or she acted in fulfilment of a duty mandated by the religion in question ${ }^{76}$. Up until now dress code issues were rarely brought to the ECtHR, although they could be covered by Article 9 of the ECHR, because they undisputedly infringe freedom of religion. However, it has to be analysed in every cases if this interference is proportionate and if it is "necessary in a democratic society". The analysed decisions of the Court suggest that:

1) Article 9 of the ECHR was raised by the applicants alone or in a context with Article 14 of the ECHR (mostly a discrimination because of religion and because of the sex), but the ECtHR has not considered a discrimination clause;

2) a State's religious neutrality was raised by the ECtHR to claim that imposing restrictions regarding wearing religious symbols by a state officials was legitimate;

3) Muslim religious symbols have dominated the discourse about wearing religious symbols at work, but Catholic symbols were also addressed by the Court;

4) a small Catholic cross is not a piece of jewelry worn purely for decorative reasons but it is a manifestation of religion;

5) most cases concerned persistent wearing of religious symbols;

6) in most case employers at first issued a warning to their employers indicating that their employees have not obeyed dress code and it was only then when other steps were taken.

${ }^{76}$ Cf. Eweida, $§ 82$. 


\section{BIBLIOGRAPHY:}

Balcerzak, M., Zagadnienie precedensu w prawie międzynarodowym praw człowieka, Toruń 2008.

Brittain S., The Relationship Between the EU Charter of Fundamental Rights and the European Convention on Human Rights: an Originalist Analysis, „European Constitutional Law Review” 2015, Vol. 11, No. 03.

Búrca G. de, After the EU Charter of Fundamental Rights: The Court of Justice as a Human Rights Adjudicator?, „Maastricht Journal of European and Comparative Law” 2013, Vol. 20, No. 2.

Búrca G. de, The Evolution of EU Human Rights Law [in:] The evolution of EU law, P. P. Craig, G. de Búrca (eds.), Oxford; New York 2011.

Dörre-Nowak D., Ochrona godności i innych dóbr osobistych pracownika, Warszawa 2005.

Garlicki, L., Wartości lokalne a orzecznictwo ponadnarodowe - „kulturowy margines oceny” w orzecznictwie strasburskim?, „Europejski Przegląd Sądowy” 2008, No. 4.

Gronowska B., Europejski Trybunał Praw Człowieka. W poszukiwaniu efektywnej ochrony praw jednostki, Toruń 2011.

Gronowska B., Gloss on the judgment of the European Court of Human Rights of 25 October 2018 in case E.S. v. Austria, appl. No. 38450/12, „Ius Novum” 2019, Vol. 13, No. 2.

Gronowska B., Maliszewska-Nienartowicz J., The EU Charter on Fundamental Rights - do we really need it? [in:] European Union at the Crossroads: the Need for Constitutional and Economic Changes, Toruń 2007.

Gronowska, B., Sadowski, P., Treatment of Prisoners - International and Polish Perspective, Toruń 2019.

Howard E., Islamic headscarves and the CJEU: Achbita and Bougnaoui, „Maastricht Journal of European and Comparative Law" 2017, Vol. 24, No. 3.

Janicka D., Jurysdykcja państwa niemieckiego w warunkach wielokulturowego społeczeństwa - kilka wybranych przykładów ze szczególnym uwzględnieniem orzecznictwa administracyjnego i konstytucyjnego, „Studia Iuridica Toruniensia” 2015, Vol. 15.

Jasudowicz T., Między sumieniem a orzecznictwem Europejskiego Trybunału Praw Człowieka, „Polski Rocznik Praw Człowieka i Prawa Humanitarnego” 2018, Vol. 8.

Londras F. de, Dzehtsiarou K., Managing Judicial Innovation in the European Court of Human Rights, „Human Rights Law Review” 2015, Vol. 15, No. 3.

Mowbray A., The Creativity of the European Court of Human Rights, „Human Rights Law Review" 2005, Vol. 5, No. 1. 
Muir E., The Fundamental Rights Implications of EU Legislation: Some Constitutional Challenges, „Common Market Law Review” 2014, Vol. 51, No. 1.

Nowicki M.A., Wokół Konwencji Europejskiej. Komentarz do Europejskiej Konwencji Praw Człowieka, Warszawa 2017.

Pavlidou, K., Religious Expression in the Workplace Before the European Court of Human Rights and the Court of Justice of the European Union: Discriminating Against a Fundamental Right? [in:] Applying Non-Discrimination Law, Goulas, D., Kofinis, St. (eds.), Thessaloniki 2018.

Sadowski P., A Safe Harbour or a Sinking Ship? On the Fundamental Rights in Recent Judgments of the CJEU on Asylum., „European Journal of Legal Studies” 2019, Vol. 11, No. 2.

Sadowski, P., Wspólny Europejski System Azylowy - historia, stan obecny i perspektywy rozwoju, Toruń 2019.

Skwarzyński M., Protecting conscientious objection as the "hard core" of human dignity, „Ius Novum” 2019, Vol. 13, No. 2.

The European Court of Human Rights and the freedom of religion or belief: the 25 years since Kokkinakis, J. Temperman, T.J. Gunn, M.D. Evans (eds.), Series „Studies in religion, secular beliefs and human rights”, volume 13, Leiden; Boston 2019.

Zieliński, T., Rozdział I. Problemy części ogólnej prawa pracy [in:] Prawo pracy RP w obliczu przemian, M. Matey-Tyrowicz, T. Zielinski (eds.), Warszawa 2006.

Żołyński, J., Prawo pracy - prawo prywatne czy prawo publiczne. Rozważania na tle charakteru umowy o pracę, „Studia z zakresu prawa pracy i polityki społecznej” 2016, No. 23. 
